\title{
56. MORPHOLOGY AND BASEMENT STRUCTURES OF THE GOBAN SPUR CONTINENTAL MARGIN (NORTHEASTERN ATLANTIC) AND THE ROLE OF THE PYRENEAN OROGENY1
}

\author{
Jean-Claude Sibuet, Benoît Mathis, \\ Léo Pastouret, ${ }^{2}$ Jean-Marie Auzende, Jean-Paul Foucher, Peter M. Hunter, Pol Guennoc, \\ Pierre-Charles de Graciansky, Lucien Montadert, and Douglas G. Masson ${ }^{3}$
}

\begin{abstract}
A new bathymetric map, based mainly on Seabeam data, has been established for the Goban Spur area during a postcruise survey of DSDP Leg 80 . Using both Seabeam data and a new series of eight seismic profiles obtained perpendicular to the continental margin, we have constructed a new detailed structural map of the Goban Spur continental margin which clearly reveals Caledonian and Variscan trends. Both the thinning of the Goban Spur continental crust, from Early Cretaceous (late Cimmerian phase) to middle Albian time, and subsequent widening of the adjacent oceanic domain, from middle Albian to Campanian time, resulted from tensional movements in a N70 direction which followed Caledonian trends. During the rifting phase, the tops of the tilted fault blocks remained close to sea level. The rapid subsidence of the margin seems to have occurred in the early Albian during the last stage of rifting.

Eocene intraplate deformation affected the whole Goban Spur continental margin, but is particularly evident at the Pastouret Ridge, a reactivated oceanic fracture zone. The oceanic domain underwent a slight intraplate compression, which fractured the old oceanic crust through its entire thickness, probably along previous zones of weakness, such as fracture zones.
\end{abstract}

\section{INTRODUCTION}

During DSDP Leg 80, four sites (548-551) were drilled on the starved continental margin of Goban Spur and on the adjacent Porcupine Abyssal Plain (Figs. 1 and 2). The main objectives of this cruise were to investigate the structural evolution and depositional history of a series of tilted fault-blocks and half-grabens and their thin Cretaceous and Tertiary cover.

During October 1983, a CNEXO (Centre National pour l'Exploitation des Océans) postcruise survey was conducted in this area on the R/V Jean Charcot (Fig. 3), equipped with a bathymetric mapping system and a single-channel high-speed seismic-reflection survey system. Sound sources were two 1.5-1 water guns or four 9-1 air guns. Altogether, $2300 \mathrm{~km}$ of profiles were acquired. As Seabeam gives the bathymetry in a band about twothirds as wide as water depth, the survey was designed to avoid any ambiguity about the lateral extension and correlation of morphologic features from profile to profile over the entire surveyed area (Fig. 3). The postrift sedimentary cover is thin, so most of the basement features are recorded in the morphology, and their trends have been clearly established.

In this chapter, we present a new bathymetric map (Fig. 2) based on all available conventional, Seabeam,

\footnotetext{
${ }^{1}$ Graciansky, P. C. de, Poag, C. W., et al., Init. Repts. DSDP, 80: Washington (U.S. Govt, Printing Office).

2 Deceased September 14, 1983.

3 Addresses: (Sibuet, Pastouret, Auzende, Foucher) Centre Océanologique de Bretagne, B. P. 337, 29273 Brest Cedex, France; (Mathis) GIS Octanologie et Géodynamique, Faculté des Sciences, Avenue Le Gorgeu, Brest, France; (Hunter, Masson) Inst. of Oceanographic Sciences, Brook Road, Wormley, Surrey, U. K.; (Guennoc) Bureau de Recherches Géologiques Sciences, Brook Road, Wormley, Surrey, U. K.; (Guennoc) Bureau de Recherches Géologiques
et Minières, Centre Océanologique de Bretagne, B. P. 337, 29273 Brest Cedex, France; (de Graciansky) École Nationale Supérieure des Mines, 60 Boulevard Saint-Michel, 75272 Paris Cedex 06, France; (Montadert) Institut Français du Pétrole, 1-4 Avenue de Bois-Préau, 92506 Rueil Cedex, France.
}

and GLORIA data, and a map of basement features (Fig. 3) showing the main structural trends. These data are examined in the light of drilling results from Leg 80 and data from observations and sampling during recent dives of the Cyana submersible on the Pendragon Escarpment and on King Arthur's Castle (Fig. 2). We also discuss these data within the regional geological framework, showing that the Goban Spur continental margin was formed in an area previously affected by the Caledonian and Variscan orogenies. And we examine the intraplate consequences of the Pyrenean orogeny, especially as regards the oceanic domain, where a new bathymetric feature, named the Pastouret Ridge, has been discovered, and where the entire thickness of ocean crust has clearly been faulted.

\section{REGIONAL TECTONIC SETTING}

The Goban Spur continental margin, about $200 \mathrm{~km}$ long, is located south of the Porcupine Sea Bight (Fig. 1 ), and it results from the relative motion of North America and Europe. It was created by crustal thinning during a rifting phase dated Early Cretaceous (late Cimmerian phase) to middle Albian (Masson et al., this vol.). The end of this rifting phase corresponds to the first creation of ocean crust. Southeastward of the Goban Spur continental margin, the Celtic margin is a result of the separation of Iberia and Europe. Although the rifting phase also started there during the late Cimmerian phase (Late Jurassic-Early Cretaceous), the onset of spreading has been dated as Aptian to middle Albian (Montadert, Roberts, de Charpal, et al., 1979).

The Goban Spur continental margin seems to have been affected, before its formation, by both the Caledonian and Variscan orogenies, and by their related tensional phases and wrench-faulting. 


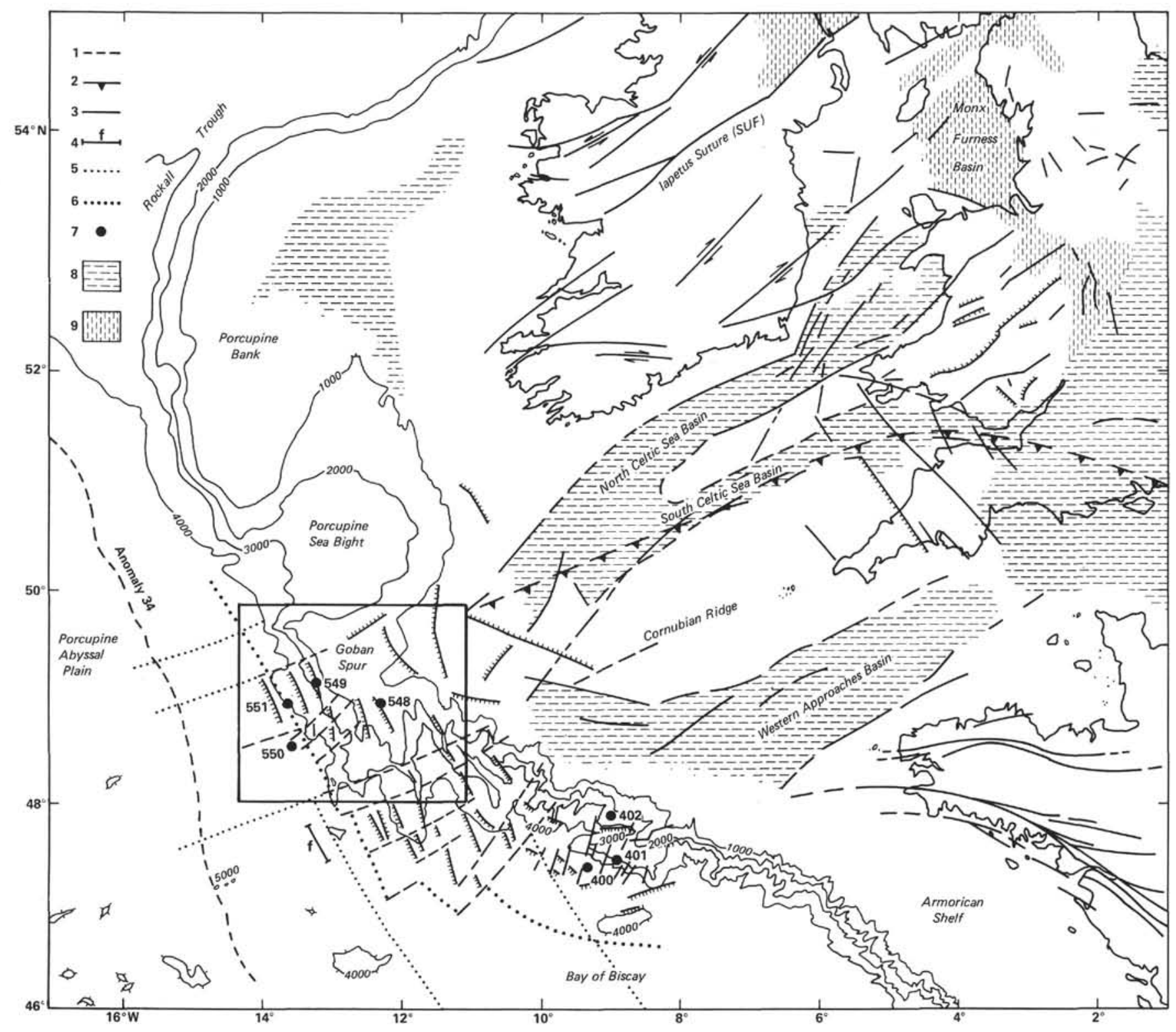

Figure 1. Generalized sketch of southwestern Europe, indicating the location of the Goban Spur survey done with the Jean Charcot during the Norestlante I cruise. (Bathymetry in meters.) Key to symbols (upper left corner): 1 = Faults in Ireland (from Max et al. [1983]; in Great Britain and in the Celtic Sea, Pegrum and Mounteney [1978]; on the continental margins, Montadert, Roberts, de Charpal, et al. [1979] and this study). 2 = Variscan front from Gardiner and Sheridan (1981). $3=$ Normal or listric faults. $4=$ Location of the seismic profile shown in Figure $9.5=$ Theoretical directions of the initial opening of the North Atlantic Ocean (Olivet et al., in press). $6=$ Continent-ocean boundary (Montadert, Roberts, de Charpal, et al., 1979, and Masson et al., this vol.). 7 = DSDP sites drilled during Legs 48 and $80.8=$ Approximate present limit of Jurassic sediments (Pegrum and Mounteney, 1978). 9 = Triassic basins.

\section{Chronology and Nature of Paleozoic Deformations}

The Caledonides resulted from the collision of continents that closed the Iapetus Ocean between the middle Silurian (420 m.y. ago; Paleozoic ages from Van Eysinga [1975] geological timetable; Mesozoic and Cenozoic ages from Odin [1982]) and the early Devonian (380 m.y. ago). The Iapetus Suture, located along the Southern Uplands Fault (Fig. 1), follows the general NE-SW orientation of the Caledonides fold belt (Leggett et al., 1983), and lies in the direct prolongation of the northwestern border of the Porcupine Sea Bight.
Between mid-Devonian and early Carboniferous time (365-335 m.y. ago), a large sediment basin, the Cornish-Rhenish Basin (Ziegler, 1978, 1981) developed under a tensional setting in an area stretching from Germany to the Celtic shelf. The position of the northern boundary of the Cornish-Rhenish basin is at present poorly documented. Between the late early Carboniferous (late Visean, 325 m.y. ago) and the middle late Carboniferous (late Westphalian, 295 m.y. ago), the Cornish-Rhenish Basin was incorporated into the Variscan deformation belt. Because the Variscan facies patterns and deformation trends were controlled primarily by the 
morphology of the southern margins of the Celtic SeaWales and Brabant massifs, Gardiner and Sheridan (1981) hypothesized that the Variscan front, previously located in southern Ireland, should follow the arcuate Bristol Channel lineament, which flanks the Celtic Sea-Wales Massif (Fig. 1). If their hypothesis is correct, the Variscan front could be coincident with the Goban Fault (Fig. 2), which lies immediately north of DSDP Sites 549 and 551 (Fig. 1) (Gardiner and Sheridan, 1981; Dingle and Scrutton, 1979). This new definition of the Variscan front may explain why there is no evidence of WNW-ESE Variscan structural influence in the Celtic Sea (as in Brittany), and why basement reactivation during the Mesozoic occurred mainly along the ENE-WSW and NE-SW Caledonian structural trends. Therefore, the previous location of the Variscan front in southern Ireland is not rejected, because this feature is associated there with clear strike-slip faulting (Lefort, this vol.) and affects the whole continental crust (SWAT profile, Matthews, pers. comm.).

Granite intrusions of Cornwall and of the Cornubian Ridge, marked by negative gravity anomalies (Sibuet 1972, 1973), and granites dredged just south of Goban Spur (Pautot et al., 1976) are presumed to be of Variscan origin, and are aligned on a trend parallel to and $100 \mathrm{~km}$ southeast of the Variscan front. Northwest of the front, Variscan deformations seem only to reflect localized basement movements allied with lithological variations in a series of disconnected basins (Gardiner and Sheridan, 1981).

Late Variscan wrench-faulting, dated late Carboniferous to early Permian (Stephanian, 285 m.y. ago, to Autunian, 270 m.y. ago) occurred along the previous NE-SW Caledonian and Variscan trends, but also along the conjugate directions, and is considered to have been a transitional stage between the closing of the Paleozoic oceans and the opening of the Mesozoic ones (e.g., Arthaud and Matte, 1977; Russell and Smythe, 1983).

In the middle Permian, a general period of extension began, marked by subsidence in the Celtic Sea, the Bristol Channel, the Western Approaches Basin, and the areas of the future plate margins. These features continued to subside during the Triassic (204-245 m.y. ago), when clear graben features appeared (Kent, 1978). The overall Triassic extension heralded the breakup of Pangaea. By late Triassic time, the Variscan fold belt expressed only disjointed low relief within the monotonous flat plain of northwestern Europe (Ziegler, 1978). But until the Early Cretaceous crustal separation was achieved in the Bay of Biscay and the North Atlantic, most of northwestern Europe was subjected to regional extension, especially in the Porcupine Sea Bight, Celtic Sea, Bristol Channel, and Western Approaches Basin, where thick sedimentary strata accumulated (Fig. 1).

In conclusion, the geological development of the Goban Spur area seems to have been largely controlled by structural and physiographic features created during the Caledonian orogeny. The Variscan orogeny also affected this area, since the Variscan front seems to be located southeast of the Porcupine Sea Bight. Older NE-SW Caledonian features were probably reactivated during the
Variscan orogeny. During the late Variscan strike-slip faulting, the conjugate NW-SE trends appeared for the first time. Then, during the Permian to Triassic tensional phase, both conjugate trends were occupied by normal and shear faults.

\section{MORPHOLOGY OF THE GOBAN SPUR CONTINENTAL MARGIN}

\section{New Bathymetric Map}

The new bathymetric map of the Goban Spur area, constructed from data acquired by conventional largeaperture echo-sounders and the Seabeam and GLORIA systems, is presented in Figure 2.

The Seabeam system is a multibeam echo-sounder comprising 16 adjacent narrow beams. The width of the contour swath beneath the track is approximately twothirds of the water depth (Renard and Allenou, 1979). The GLORIA Mark II of the Institute of Oceanographic Sciences is a dual-scan sonar towed at shallow depths, with a maximum scanning range of $30 \mathrm{~km}$ on each side of the ship's track (Somers et al., 1978). GLORIA sonographs have been produced at the same scale as the Seabeam data (working scale, $1: 250,000$ at $38^{\circ} \mathrm{N}$ ).

The track control of Seabeam data is shown on Figure 3. Detailed Seabeam maps established during the Marmor cruise (Pastouret et al., 1982) for Austell Spur, King Arthur's Castle, and the Pendragon Escarpment have been incorporated in the final map (Fig. 2), and are located in Figure 3. Conventional bathymetric data (e.g., Berthois, 1966; Laughton et al., 1975) have been used to fill the gaps in the Seabeam data. North of $49^{\circ} 20^{\prime} \mathrm{N}$, the bathymetric map of Hunter and Kenyon (in press) has been incorporated. Depths are in uncorrected meters $(1500 \mathrm{~m} / \mathrm{s})$. In addition, GLORIA data available for the vicinity of Austell Spur and King Arthur's Castle and King Arthur Canyon have been used to constrain the direction of trends identified on both bathymetric and GLORIA data.

\section{Morphology}

The Goban Spur continental margin is limited to the northwest by the Porcupine Sea Bight and to the southeast by the Jean Charcot Escarpment (Fig. 2). The general orientation of this escarpment is $\mathrm{N} 70^{\circ}$, corresponding to the Caledonian or late Hercynian directions, although this $\mathrm{N} 70^{\circ}$ direction seems to be slightly offset by ESE-WNW trends, which are also the fault trends observed on the Celtic margin (Fig. 1).

The Jean Charcot Escarpment was called "South Boundary Fault" by Dingle and Scrutton (1979) and the Jean Charcot Escarpment by Pastouret et al. (1982). We proposed to retain the latter designation, mainly because the Dingle and Scrutton name was defined only with respect to the Goban Spur continental margin.

The NW-SE-trending Pendragon Escarpment and another NW-SE escarpment-located $35 \mathrm{~km}$ southeastward, close to DSDP Site 551, and named "Outer Boundary Fault" by Dingle and Scrutton (1979) - are offset or stopped by NE-SW faults such as the Goban Fault (Fig. 2). 


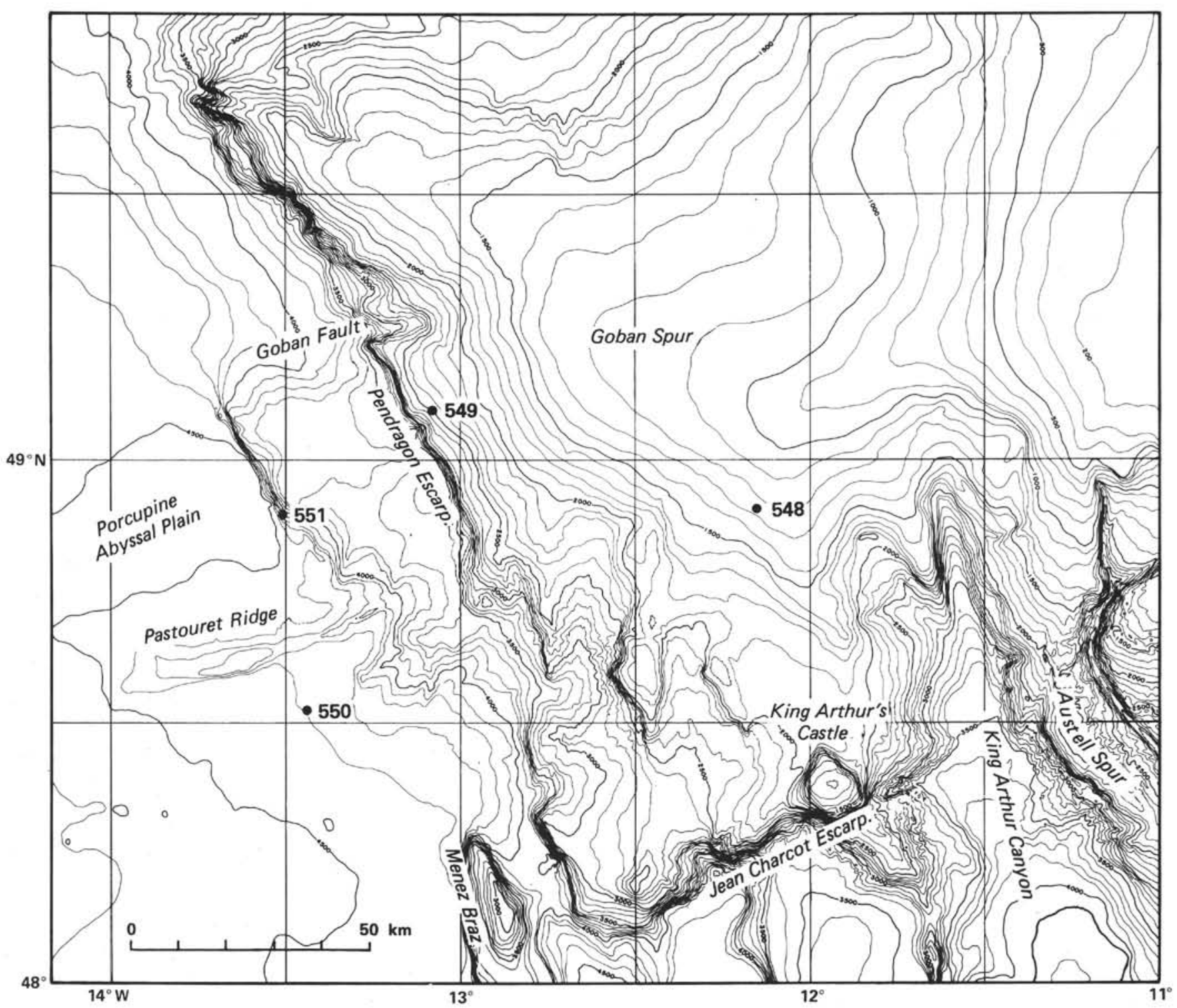

Figure 2. Bathymetric map, in Mercator projection, of the Goban Spur continental margin, established from Seabeam data (locations of tracks and local surveys [Pastouret et al., 1982] in Figure 3), conventional data (Berthois, 1966; Laughton et al., 1975; Hunter and Kenyon, in press), and unpublished GLORIA data from IOS. Depths are in uncorrected meters $(1500 \mathrm{~m} / \mathrm{s})$. Contour spacing every 100 meters. Locations of DSDP sites drilled during Leg 80 are shown. The Pastouret Ridge is a newly named bathymetric feature.

On the Porcupine Abyssal Plain, $4500 \mathrm{~m}$ deep, a new bathymetric feature, oriented roughly $\mathrm{N} 70^{\circ}$, about $50 \mathrm{~km}$ long and $300 \mathrm{~m}$ high, was discovered during the Norestlante cruise. We propose to name this feature "Pastouret Ridge," in memory of Léo Pastouret, who was particularly involved in the geological investigations of the Celtic and Goban Spur continental margins.

North of the Jean Charcot Escarpment, the bathymetry of the Goban Spur continental margin is complicated by the presence of several NNW-SSE-trending canyons, such as King Arthur Canyon. South of the Jean Charcot Escarpment, the average water depth over the continental margin is more than $1000 \mathrm{~m}$ greater than north of the escarpment. This portion of the continental margin, at the intersection of the Goban Spur and Celtic continental margins, has probably been affected by the interaction of tectonic movements linked to the formation of both margins during the Early Cretaceous. Nevertheless, the main structural trends of this area, such as Granite Cliff, Menez Bihan (Pautot et al., 1976), Menez Braz, and the Pendragon Escarpment, are oriented $\mathrm{N} 330^{\circ}$.

We infer from the directions of morphologic trends that the formation and evolution of this portion of the North Atlantic continental margin have been controlled mainly by the previous Caledonian and late Variscan orogenic trends, as previously indicated by continental geological evidence.

\section{STRUCTURE AND GEOLOGICAL EVOLUTION OF THE GOBAN SPUR CONTINENTAL MARGIN}

During the Norestlante cruise, $2300 \mathrm{~km}$ of single-channel seismic reflection profiles were collected in the area 


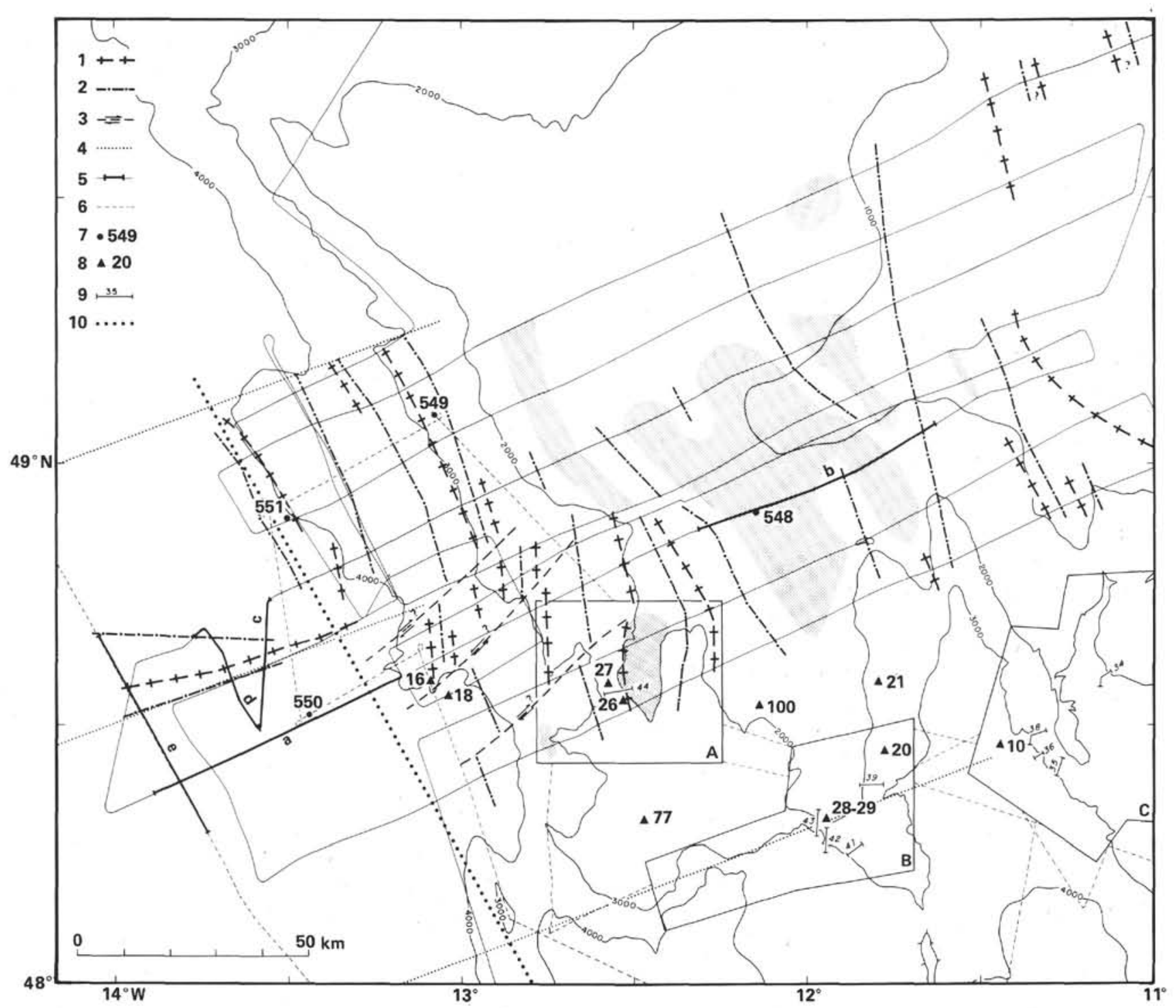

Figure 3. Structural map of the Goban Spur continental margin, established using seismic and Seabeam data from the Jean Charcot Norestlante I cruise. Simplified bathymetry from Figure 2. Boxes A, B, and C are previous Seabeam detailed surveys done in 1979 during the Jean Charcot Marmor cruise (Pastouret, et al., 1982). Shaded areas correspond to the eroded surfaces of tilted blocks. Key to symbols (upper left corner): 1 = Axis of highs. 2 = Axis of depressions. 3 = Possible faults. 4 = Theoretical directions of the initial opening of the North Atlantic Ocean (Olivet et al., in press). 5, thin lines = Locations of seismic and Seabeam profiles used in this study; thick lines = Location of seismic profiles a to e shown in Figs. 4 to 6 and 8.6 = Complementary Seabeam tracks used to establish the bathymetric map of Figure 2. 7 = DSDP sites drilled during Leg 80.8 = Dredgings (Auffret et al., 1979; Dingle and Scrutton, 1979). $9=$ Locations of Cyana dives. 10 = Continent-ocean boundary.

of Goban Spur (Fig. 3). Two types of seismic sources were used: two 1.5-1 water guns towed at 10 knots with a shot spacing of $10 \mathrm{~s}$; and four 9-1 air guns towed at 6 knots with a shot spacing of $30 \mathrm{~s}$ (in order to have better penetration and to deploy sonobuoy refraction experiments).

Eight parallel profiles with 8-mile spacing were collected in the region of Leg 80 sites, from the continental shelf to the typical oceanic domain (Fig. 3). Their ENEWSW orientation is perpendicular to the direction of the continental margin. Because Seabeam data are available in real time, it was possible to identify the geometry of all features marked by topographic expression and to follow their lateral extension and orientation, and consequently to correlate them from profile to profile. A few complementary short profiles were implemented to follow structures or to specify the termination of structures.

\section{Basement Structures of the Goban Spur Continental Margin}

The starved Goban Spur continental margin is characterized by a series of tilted fault-blocks, horsts, and grabens trending roughly parallel to the NW-SE direction of the continental slope (Montadert, Roberts, de Charpal, et al., 1979; Dingle and Scrutton, 1979; Masson et al., this vol.). The position of the continent-ocean boundary (Figs. 1 and 3) has been located on the basis of magnetic, seismic, and drilling data (Montadert, de Charpal, et al., 1979; Masson et al., this vol.). 
Using both Seabeam and seismic data, the positions of depressions and highs within the rift system have been inferred over the whole area (Fig. 3). These structures trend N-S or NNW-SSE. North of the surveyed area, the NNW-SSE features are interrupted by the Goban Fault, oriented $\mathrm{N} 70^{\circ}$, as shown on the bathymetric map (Fig. 2) and known from the previous work of Dingle and Scrutton (1979). Near $48.5^{\circ} \mathrm{N}, 13^{\circ} \mathrm{W}$, three tectonic lines of discontinuity, oriented $\mathrm{N} 45^{\circ}$, are visible. Also in this area, N-S trends are recognized. On the basis of this detailed survey, we infer an abrupt change in the trends of structures or a juxtaposition of different structural provinces, rather than a progressive bending of structures from $\mathrm{N} 335^{\circ}$ to $\mathrm{N} 360^{\circ}$, as suggested by Masson et al. (this vol.). The three tectonic lines of discontinuity just mentioned follow the previous Caledonian and Variscan trends, and delimit different structural provinces. Horizontal movements of unknown limited extent could have taken place along these lines during the rifting phase.

In the oceanic domain, the sediments of the Porcupine Abyssal Plain bury the basement features, except for the topographically high Pastouret Ridge (Figs. 25). The southern flank of the Pastouret Ridge is a fault trending $\mathrm{N} 71^{\circ}$, which is almost exactly the direction of the Goban Fault, of the Jean Charcot Escarpment, and of the theoretical directions of the early opening of the North Atlantic Ocean in this region (Le Pichon et al., 1977; Olivet et al., in press; Figs. 1 and 3). This suggests that the Pastouret Ridge is an oceanic fracture zone which has been subsequently reactivated.

Consequently, the formation both of the Goban Spur continental margin, from the Early Cretaceous (130 m.y. ago) to the middle Albian (100 m.y. ago), and then of the adjacent oceanic domain, from the middle Albian (100 m.y. ago) to the Campanian (Anomaly 33, 80 m.y. ago), resulted from $\mathrm{N}^{\circ} 0^{\circ}$ tensional movements which were parallel to the Caledonian trends. This is because initial plate motions are severely constrained by previous structural features of the continents, which become lines of weakness that guide early motions of plates (e.g., Sibuet and Mascle, 1978; Olivet et al., in press). In the case of the North America-Eurasian continent (Pangaea), the ENE-WSW Caledonian and Hercynian directions preferentially controlled the initial motion of continents along the oldest direction of the Charlie-Gibbs Fracture Zone (e.g., Olivet et al., 1974), which also corresponds to the orientation of the northern border of Porcupine Bank and of the southern Rockall Bank.

\section{Nature and Significance of Pre-Rift Basement Structures}

The seismic profile of Figure 6 shows that the pre-rift basement is not homogeneous but consists of alternate opaque and layered sequences. The inclined layered sequences (e.g., between 4.30 and 5.00 on Fig. 6) are prerift sedimentary sequences, older than Late Jurassic, which tilted during rifting. The progressive tilting and the contemporaneous sedimentation are evidenced here by the convergence of syn-rift reflectors toward the ocean (Fig. 6 between 5.00 and 5.20). The continental basement was sampled by drilling at Sites 548 and 549 and by dredging (Auffret et al., 1979; Dingle and Scrutton, 1979) on the southern part of Goban Spur (Fig. 3). In 1982, during the Cymor II cruise, several sampling dives (Fig. 3) with the Cyana submersible were made on the Pendragon Escarpment, King Arthur's Castle, and Austell Spur. Preliminary results of these dives are compared with the drilling and dredging results.

At DSDP Sites 548 and 549, the basement consists of middle (365 m.y. old) to upper (350 m.y. old) Devonian graphitic quartzites and black shales (Lefort et al., this vol.) belonging to the Hercynian basement. Nearly vertical bedding, a slight metamorphic cleavage, and micaceous lineations indicate Hercynian tectonism (de Graciansky et al., in press).

Sampling during the Cyana dives on King Arthur's Castle and the Pendragon Escarpment (Figs. 3 and 7) recovered numerous sedimentary and metamorphic $\mathrm{Pa}$ leozoic rocks. Cyana dive 44 (Fig. 3), on the Pendragon Escarpment, sampled a structural situation similar to that of DSDP Site 549. The Paleozoic basement, sampled at water depths between 2200 and $2500 \mathrm{~m}$, is composed of schists and gneisses (Fig. 7) of higher metamorphic grade than the rocks recovered at DSDP Sites 548 and 549. Five dives (39-43) were made around King Arthur's Castle (Fig. 3). The lithologic description (Fig. 7) shows that the basement there also consists of Paleozoic schists and gneisses, as for the basement sampled on dive 44. Abundant fragments of chloritic schists affected by a low-grade metamorphism (Auffret et al., 1979; Dingle and Scrutton, 1979) have also been dredged in this area.

Granitic rocks, mainly granodiorites, have been dredged on the Granite Cliff and Menez Bihan, two features just south of the Jean Charcot Escarpment (Fig. 3). $\mathrm{Rb}-\mathrm{Sr}$ and $\mathrm{K}-\mathrm{Ar}$ dating give a $275 \mathrm{~m}$.y. (total-rock) or 290 m.y. (biotite) age for these rocks attributed to the Hercynian basement (Auffret et al., 1979). In the Goban Spur area, Upper Jurassic shallow-water limestones characteristic of intertidal environments were reported only on the Granite Cliff (Auffret et al., 1979), although these samples may not have been in place. It is only at the level of DSDP Site 401, $200 \mathrm{~km}$ southeastward, that white shallow-water limestones of perireefal environment have been reported (Site 401 chapter, Montadert, Roberts, et al., 1979).

Thus, in the Goban Spur area, basement rocks are mainly middle Devonian (365-m.y.-old) and lower Carboniferous (335-m.y.-old) schists, gneisses, and limestones emplaced in shallow-water conditions, with some granitic intrusions. These Paleozoic rocks were affected by metamorphism during the Variscan phase, and show an increasing metamorphic grade from Sites 548 and 549 toward the south. These observations are compatible with a location of the Variscan front in the northern part of the Goban Spur area, as hypothesized by Gardiner and Sheridan (1981) (Fig. 1), and with a southward bending of the main Variscan deformation-trend from Brittany in the direction of the Iberian Peninsula replaced in its initial position (Sibuet, 1973). The Celtic Sea basins were intruded during the Variscan orogeny by 


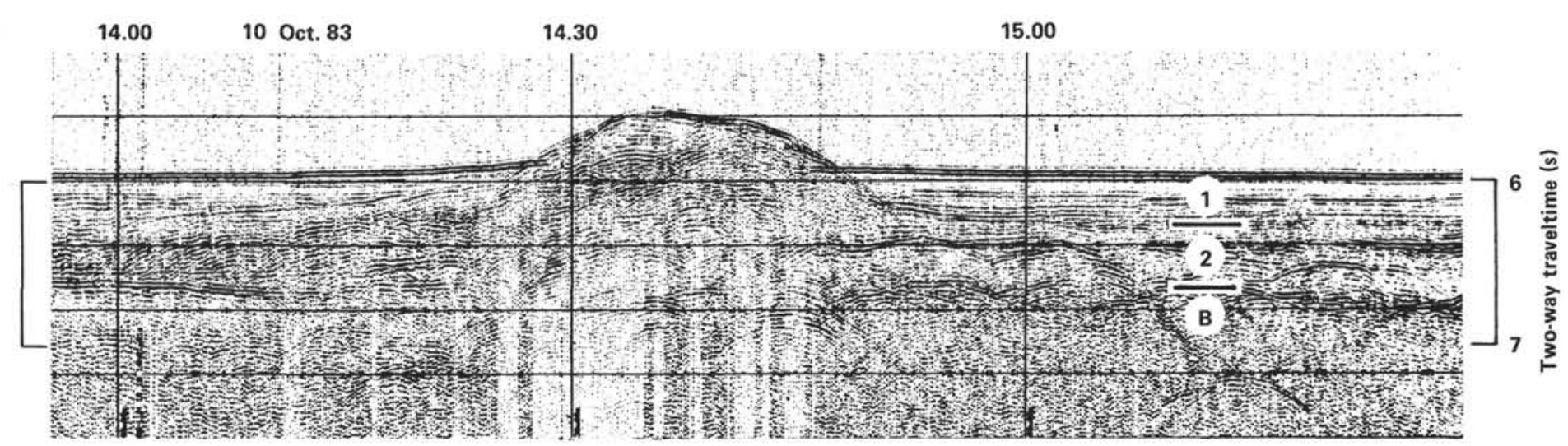

$5 \mathrm{~km}$

SE

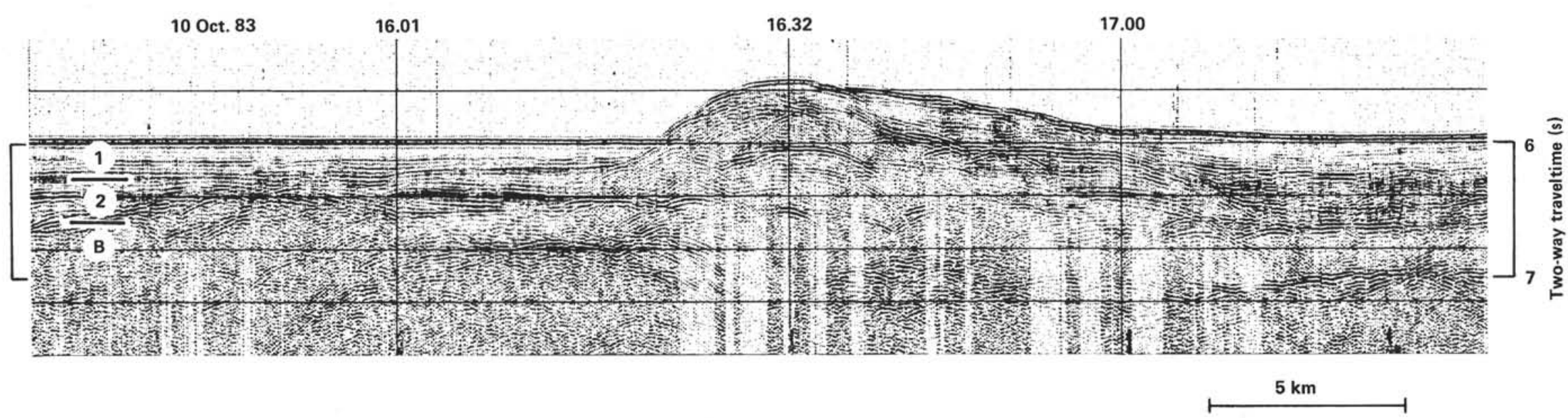

Figure 4. CNEXO high-speed single-channel seismic profiles across the Pastouret Ridge and located as profile c (N-S) and d (SE-NW) in Figure 3. The main acoustic units are: Unit 1, upper Oligocene to Present; Unit 2, upper Albian to lower Eocene; B, oceanic basement. 


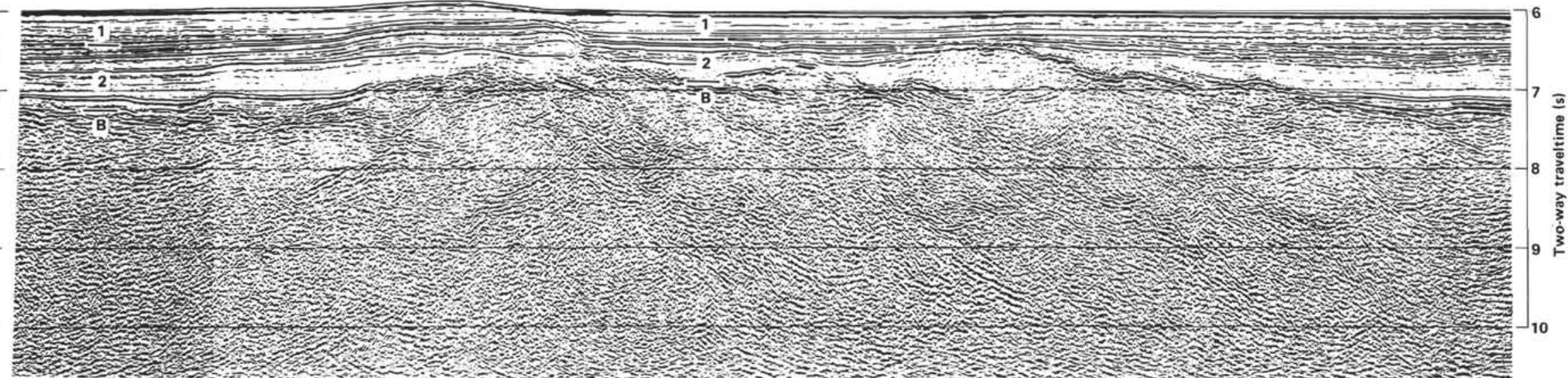

Figure 5. IOS multichannel seismic profile CM 05, migrated by IFP across the western part of the Pastouret Ridge and located as profile e in Figure 3. The main acoustic units are: Unit 1, upper Oligocene to Present; Unit 2, upper Albian to Lower Eocene; B, oceanic basement.

SW

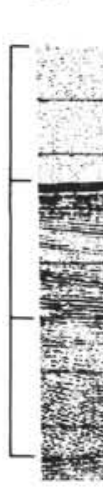

\section{DSDP}

$\square^{5}$

4.30
11 Oct. $83 \quad 4.00$

5.00

5.30

6.00

NE

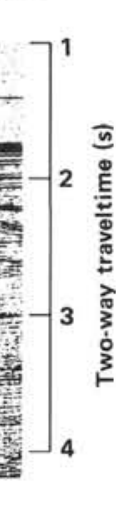

Figure 6. CNEXO high-speed (11 knots) single-channel seismic profile using two waterguns and shown as profile b in Figure 3 . Drilling at Site 548 penetrated through the eroded surface of a tilted block. The main acoustic units are: Unit 1, upper Oligocene to Present; Unit 2, upper Albian to lower Oligocene; B, pre-rift. 

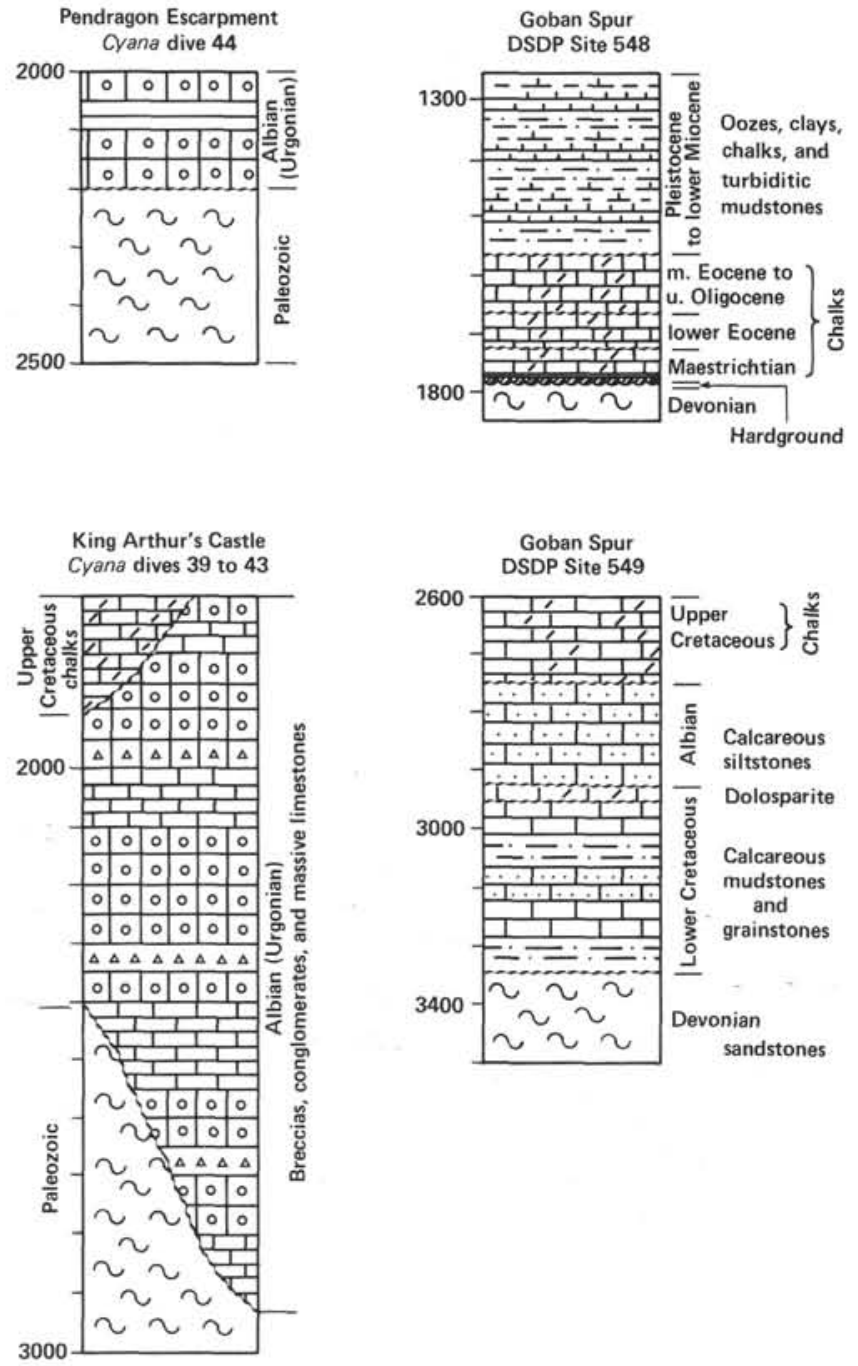

Figure 7. Lithostratigraphic comparisons between Sites 548 and 549, drilled on the tilted fault blocks, and Cyana dives on the Pendragon Escarpment and the flanks of King Arthur's Castle. Locations of DSDP sites and Cyana dives in Figure 3. Depths are in meters below sea level.

granites belonging to the batholithic axis (Sibuet, 1972, 1973), which can be followed straight from Cornwall to the foot of the continental margin on Granite Cliff, south of the Jean Charcot Escarpment (Fig. 1).

\section{Nature and Significance of Syn-Rift Deposits}

In the Goban Spur area, a rifting phase began in the Early Cretaceous and ended in the latest early Albian (Masson et al., this vol.). At Site 549, the oldest syn-rift sediments are shallow-water interbedded calcareous and noncalcareous sandy mudstones and mudstones (Barremian, 113 m.y. old) (Site 549 chapter, this vol.). These sediments are overlain by a thin dolosparitic bed (Fig. 7), possibly an Aptian remnant, which in turn is overlain by a series of uppermost lower and middle Albian (98-102-m.y.-old) calcareous siltstones deposited in a bathyal environment. If the presence of this unconformity was associated with a major sea-level drop in the middle Aptian (110 m.y. ago; Vail et al., 1977), the change from a shallow-water to a bathyal environment corresponds to a post-Aptian deepening of the margin.

At Site 550, situated about $15 \mathrm{~km}$ west of the continent-ocean boundary, the oldest sediments on the ocean crust are early late Albian ( 98 m.y. old; Müller, this vol.; Sigal and Magniez, this vol.). Coupling the dating of the oldest syn-rift and the youngest post-rift sediments at Site 549 and the dating of the oldest sediments above the ocean crust at Site 550, Masson et al. (this vol.) propose to date the transition from rifting to spreading between latest early Albian and middle Albian (98-102 m.y. ago).

On the Pendragon Escarpment, at $2200 \mathrm{~m}$ water depth, Cyana dive 44 (Figs. 3 and 7) showed that an erosional unconformity exists between the Paleozoic basement and the overlying sedimentary sequence, composed of alternating conglomerates and massive limestones of the Urgonian facies. Similarly, Cyana dives 39 to 43 , on the flanks of King Arthur's Castle, (Figs. 3 and 7) showed that above the erosional unconformity there exists an alternation of conglomerates, breccias, and massive limestone layers of the Urgonian facies, deposited in the early Albian and more than $1000 \mathrm{~m}$ thick. These detritics contain reworked fragments from both the Paleozoic basement and the interbedded Urgonian limestones. This shows that, simultaneously with the building of a carbonate platform during early Albian times, major faults were active on the continental margin. In contrast, on the eastern flank of King Arthur's Castle, Upper Cretaceous chalk (200 m thick) was deposited in a deeper environment.

Along the Meriadzek Escarpment and Shamrock Canyon, located on the Armorican continental margin in the vicinity of DSDP Leg 48 sites, observations from a submersible also suggest an important phase of faulting dated early Albian or just after, also linked to the onset of spreading in the Bay of Biscay (Groupe Cymor, 1981).

\section{Interpretation in Terms of Rifting Processes}

During the rifting phase, in which tilted fault-blocks developed and rotated, it seems that the tops of the tilted blocks remained close to sea level, as shown by the observations at Site 549, on the Pendragon Escarpment, and on King Arthur's Castle. This could have resulted from the relative uplift of the oceanward parts of the blocks during rotation along their longitudinal axes, which would have compensated for the regional subsidence due to stretching.

During the early Albian, there was a distinct increase of subsidence, probably because most of the tilting of the deeper blocks had occurred during the beginning of the rifting phase, so the degree of subsidence should be directly linked to the increase of the stretching factor in the upper part of the continental margin.

Finally, in the middle Albian, the post-rift phase began, and the whole margin thermally subsided.

\section{Eocene Deformations}

The relative northward motion of Africa with respect to Eurasia, deduced from the kinematic evolution of the central and North Atlantic oceans, started in the Late Cre- 
taceous. The convergence rate was maximum from the Late Cretaceous to the late Eocene (34 m.y.), and then decreased slightly (e.g., Olivet et al., in press; Savostin et al., in press). The consequence on the Iberian Plate was a northwestward motion with respect to Europe, around a pole located southwest of Iberia. The Pyrenees and the North Spanish marginal trough resulted from this compressional phase. The plate motion lasted from the Late Cretaceous to the late Eocene, with maximum activity during the Eocene.

Linked to the relative convergent motion of Iberia and Eurasia, intraplate tectonics developed on both the Iberian Plate (e.g., Groupe Galice, 1979) and the Eurasian Plate (e.g., Montadert, de Charpal, et al., 1979; Masson and Parson, 1983). On land, numerous studies show that the deformation occurred in France, Great Britain, and Germany, and was created by compression along a $10-20^{\circ} \mathrm{N}$ direction (de Charpal et al., 1974; Bergerat and Geyssant, 1980; Letouzey and Trémolières, 1980). Following the orientations of pre-existing structures, this compression phase created strike-slip faults, reverse faults, folds, and uplifts.

On the north Biscay margin, the faulting caused the uplift and creation of the Trevelyan Escarpment; but this tectonized E-W-trending belt disappears toward the northwest. There it merges into a single strike-slip fault system, oriented NW-SE, which can be followed as far as the southern edge of Goban Spur (Montadert, de Charpal, et al., 1979). Other effects of the late Eocene deformation include elongated folds oriented broadly E-W on the Meriadzek and Trevelyan escarpments, rejuvenated rift-faults, reverse faults, and even some thrusts along pre-existing E-W discontinuities in the basement. When the basement discontinuities are oriented roughly NW-SE, as on the Armorican margin and the Gascony ridge, the N-S Eocene compression is marked essentially by faults with a strike-slip component (Montadert, de Charpal, et al., 1979).

On the Goban Spur continental margin, all the Norestlante seismic profiles (Fig. 3) show evidence of this late Eocene tectonic phase. As an example, the two seismic profiles of Figures 6 and 8, which include DSDP Sites 548 and 550 , show a slight but very clear unconformity at the limit between acoustic Units 1 and 2. This seismic unconformity, characterized by onlapping reflectors in the overlying sediments, is a consequence of a tectonic deformation. It can be traced over the whole area.

Using velocities measured on samples from Sites 548 and 550 (site chapters, Sites 548 and 550, this vol.), identification of the main stratigraphic gaps leads us to a correlation between the acoustic stratigraphy and the lithostratigraphy slightly different from the one proposed in the site chapters. The discontinuity between acoustic Units 1 and 2 is correlated with the lower Oligocene-upper Oligocene hiatus identified at $348 \mathrm{~m}$ sub-bottom at Site 548, and with the lower Eocene-upper Oligocene hiatus identified at $312 \mathrm{~m}$ sub-bottom at Site 550 .

The Pastouret Ridge is the most striking Eocene structural feature of the Goban Spur area. Illustrated by the three seismic profiles of Figures 4 and 5, the deformation there affects both the ocean crust and the overlying sediments. On the migrated section of Figure 5 (between shot-points 3100 and 3400 , in the western part of the Pastouret Ridge (Fig. 3), the deformed sediments correspond to a faulted monocline and consequently to a motion with a compressional component. Faint evidence of fracturing within the ocean crust is provided by the presence of features dipping on the outside of the Pastouret Ridge near shot-point 3200 . In the central part of the Pastouret Ridge, where its topographic relief is about $300 \mathrm{~m}$, the deformation always seems to occur along a fault oriented $\mathrm{N} 70^{\circ}$ and situated on the southern flank of the ridge. The direct correlation of the seismic units with the Site 550 lithostratigraphy allows us to establish that the end of the deformation occurred at the boundary of acoustic Units 1 and 2 and belongs to the Eocene deformation pattern. Since the orientation of the ridge coincides with the directions of the oceanic flow-lines, we conclude that the Pastouret Ridge is an Eocene rejuvenated oceanic fracture zone.

Another example of Eocene deformation is shown in Figure 9 (shot-point 1000). Reverse faulting affects both the ocean crust and the sediment layers older than Oligocene. During the Norestlante II cruise (Le Suroit, March 1984), we have demonstrated that this Eocene feature is oriented $\mathrm{N}^{\circ} 0^{\circ}$, as is the Pastouret Ridge.

The Eocene deformation observed in the Porcupine Abyssal Plain affected preferentially the previous oceanic fracture zones. Consequently, under a slight intraplate compressional component, the old ocean crust of the Porcupine Abyssal Plain has been fractured along preexisting fracture zones. This example could represent the early stage of overthrusting within the ocean crust.

Another very important point is that the features within the ocean crust can be followed down to $8.5 \mathrm{~s}$ (twoway traveltime), which is 1.5 to $2.0 \mathrm{~s}$ (two-way traveltime) below the top of the ocean crust, with a dipping angle about 25 to $35^{\circ}$ and a spacing between faults about 10 to $15 \mathrm{~km}$ (Fig. 9). If the velocity within the ocean crust is about $6 \mathrm{~km} / \mathrm{s}$, these features affect 4.5 to $6 \mathrm{~km}$ of ocean crust, which corresponds roughly to the 5 $\mathrm{km}$ expected thickness of a 100 -m.y.-old normal ocean crust. The Moho discontinuity is not visible on the profile, but it seems that the faulting affects the whole thickness of the ocean crust. Because the seismic line is oriented very near to the strike direction of the ocean crust, Masson et al. (this vol.) interpret these features as oblique crossings of normal faults of the type formed at mid-ocean ridges. We have established that parts of these features were reactivated during the Eocene compression and belong to the fracture-zone pattern.

On the northern Bay of Biscay and Goban Spur continental margins and in the adjacent oceanic domain of the Bay of Biscay and Porcupine Abyssal Plain, the Eocene intraplate deformation affects both the crust and the overlying sediments. Typical compressive structures (folds and reverse faults) seem to be more frequent along E-W trends (e.g., Cantabria, Trevelyan, Porcupine Abyssal Plain), and strike-slip faulting (with a compressive component) more frequently trends NW-SE or NE-SW (e.g., Gascony Ridge, NW-SE trend along the Armorican margin, southern part of Porcupine Sea Bight, Pas- 
SW

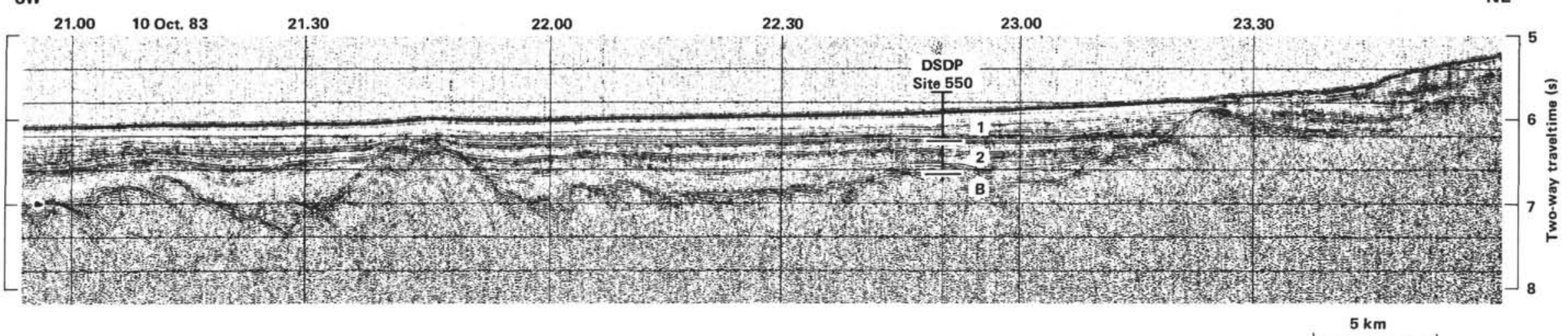

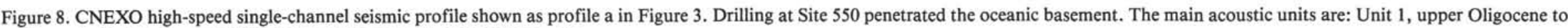
Present; Unit 2, upper Albian to lower Eocene; B, oceanic basement.

1200

1000

800

600

400

NW

$5 \mathrm{~km}$

SE

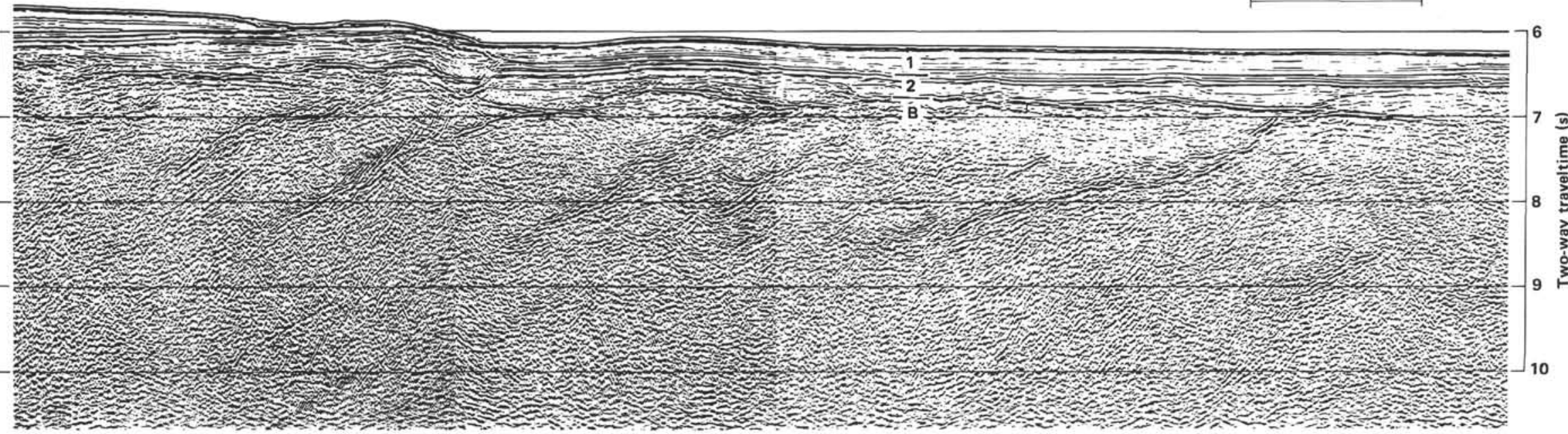

Figure 9. IOS multichannel seismic profile CM 05, migrated by IFP and located in the Porcupine Abyssal Plain as profile f in Figure 1. The main acoustic units are: Unit 1, upper Oligocene to Present; Unit 2, upper Albian to lower Eocene; B, oceanic basement. 
touret Ridge). These observations are compatible with a submeridian compression, as proposed on the basis of land data (Letouzey and Trémolières, 1980).

\section{CONCLUSIONS}

1. A new bathymetric map based on Seabeam, conventional, and GLORIA data has been established, and a structural map has been proposed based on Seabeam data and seismic profiles oriented perpendicular to the continental margin. This structural map reveals Caledonian and Variscan trends.

2. Trends in a $\mathrm{N} 70^{\circ}$ direction, corresponding to $\mathrm{Cal}-$ edonian trends, have been identified both on the thinned continental crust (Goban Fault, Jean Charcot Escarpment) and on the oceanic domain (Pastouret Ridge).

3. The continental margin and the adjacent oceanic domain resulted from continuous tensional movement along the $\mathrm{N} 70^{\circ}$ Caledonian direction from the Early Cretaceous to the Campanian.

4. Subsidence of the tops of tilted blocks in the upper part of the continental margin seems to have occurred preferentially at the end of the rifting episode during the early Albian.

5. Eocene intraplate deformation affected the whole Goban Spur continental margin.

6. Under a slight intraplate compression, the old ocean crust of the Porcupine Abyssal Plain was fractured again over its entire thickness along previous fracture zones, which are considered as zones of weakness. In particular, the Pastouret Ridge corresponds to a reactivated fracture zone.

\section{ACKNOWLEDGMENTS}

This chapter is dedicated to Léo Pastouret, who died September 14,1983 after a short illness. Léo was particularly involved in the geology of the Celtic and Goban Spur continental margins, and had initiated a large program on the evolution of these margins, using seismic profiling, Seabeam morphology, dredging, and diving. He conducted several cruises, the last one being the Cymor II cruise (summer 1982), during which the Cyana submersible was operated on the southern part of the Goban Spur continental margin. Preliminary results of the Cymor II cruise have been incorporated in this chapter.

The authors are especially indebted to the crews of the Jean Charcot and Le Suroit, and for financial support from the Centre National pour l'Exploitation des Océans. Jean-Pierre Mazé made the illustrations. René Blanchet, Guy Pautot, and Wylie Poag critically reviewed the manuscript and offered helpful suggestions. This is contribution 861 of the Centre Océanologique de Bretagne.

\section{REFERENCES}

Arthaud, F., and Matte, P., 1977. Late Paleozoic strike slip faulting in southern Europe and northern Africa: result of a right lateral shear zone between the Appalachians and the Urals. Geol. Soc. Am. Bull., 88:1305-1320.

Auffret, G. A., Pastouret, L., Cassat, G., de Charpal, O., Cravatte, J., et al., 1979. Dredged rocks from the Armorican and Celtic margins. In Montadert, L., Roberts, D. G., et al., Init. Repts. DSDP, 48: Washington (U.S. Govt. Printing Office), 995-1014.

Bergerat, F., and Geyssant, J., 1980. La fracturation tertiaire de l'Europe du Nord; résultat de la collision Afrique-Europe. C. $R$. Seances Acad. Sci., 290:1521-1524.

Berthois, L. (Ed.), 1966. Bathymetric Maps of the Continental Slope and Shelf: Paris (Centre Nat. Rech. Scientif.).

de Charpal, O., Trémolières, P., Jean, F., and Masse, P., 1974. Un exemple de tectonique de plate-forme. Les Causses majeures. Rev. Inst. Fr. Pet., 29:715-732.

de Graciansky, P. C., Poag, C. W., Cunningham, R., Loubere, P., Masson, D. G., et al., in press. The Goban Spur transect. Geologic evolution of a sediment-starved passive continental margin. Geol. Soc. Am. Bull.

Dingle, R. V., and Scrutton, R. A., 1979. Sedimentary succession and tectonic history of a marginal plateau (Goban Spur, southwest of Ireland). Mar. Geol., 33:45-69.

Gardiner, P. R. R., and Sheridan, D. J. R., 1981. Tectonic framework of the Celtic Sea and adjacent areas with special reference to the location of the Variscan front. J. Structural Geol., 3:317-331.

Groupe Cymor (Pastouret, L., Auffret, G. A., Auzende, J.-M., Beuzart, P., Dubois, P., et al.), 1981. La marge continentale armoricaine, résultats d'observation en submersible et de dragages dans le canyon Shamrock. C. R. Seances Acad. Sci., 292:741-748.

Groupe Galice (Auzende, J.-M., Jonquet H., Olivet, J.-L., Sibuet, J.-C., Auxiétre, J.-L., et al.), 1979. The continental margin of Galicia and Portugal: acoustical stratigraphy, dredge stratigraphy and structural evolution. In Sibuet, J.-C., Ryan, W. B. F., et al., Init. Repts. DSDP, 47, Pt. 2: Washington (U.S. Govt. Printing Office), 633-662.

Hunter, P. M., and Kenyon, N. H., in press. Bathymetry of Porcupine Seabight and Porcupine Bank. Institute of Oceanographic Sciences, Wormley, England.

Kent, P. E., 1978. Mesozoic vertical movements in Britain and the surrounding continental shelf. In Bowes, D. R., and Leake, B. E. (Eds.), Crustal Evolution in North-western Britain and Adjacent Regions. Geol. J. Spec. Issue, 10:309-324.

Laughton, A. S., Roberts, D. G., and Graves, R., 1975. Bathymetry of the northeast Atlantic: Mid-Atlantic Ridge to southwest Europe. Deep Sea Res., 22:791-810.

Leggett, J. L., McKerrow, W. S., and Soper, N. J., 1983. A model for the crustal evolution of southern Scotland. Tectonics, 2:187-210.

Le Pichon, X., Sibuet J.-C., and Francheteau, J., 1977. The fit of continents around the North Atlantic Ocean. Tectonophysics, 38: 169-209.

Letouzey, J., and Trémolières, D., 1980. Paleostress field around the Mediterranean since the Mesozoic from microtectonics: comparisons with plate tectonic data. Proc. 26th Int. Geol. Congr., Mem. Bur. Rech. Geol. Min., 115:261-273.

Masson, D. G., and Parson, L. M., 1983. Eocene deformation on the continental margin SW of the British Isles. J. Geol. Soc. London, 140:913-920.

Max, M. D., Ryan, P. D., and Inamdar, D. D., 1983. A magnetic deep structural geology interpretation of Ireland. Tectonics, 2:431-452.

Montadert, L., Roberts, D. G., de Charpal, O., and Guennoc, P., 1979. Rifting and subsidence of the northern continental margin of the Bay of Biscay. In Montadert, L., Roberts, D. G., et al., Init. Repts. DSDP, 48: Washington (U.S. Govt. Printing Office), 1025-1060.

Montadert, L., de Charpal, O., Roberts, D., Guennoc, P., and Sibuet, J.-C., 1979. Northeast Atlantic passive continental margins; rifting and subsidence processes. In Talwani, M., Hay, W., and Ryan, W. B. F. (Eds.), Deep Drilling Results in the Atlantic Ocean: Continental Margins and Paleoenvironment: Washington (Am. Geophys. Union), Maurice Ewing Series, 3:154-186.

Montadert, L., Roberts, D. G., et al., 1979. Site 401. In Montadert, L., Roberts, D. G., et al., Init. Repts. DSDP, 48: Washington (U.S. Govt. Printing Office), 73-124.

Odin, G. S., 1982. Numerical Dating in Stratigraphy: Chichester, England (Wiley).

Olivet, J.-L., Bonnin, J., Beuzart, P., and Auzende, J.-M., in press. Cinématique de l'Atlantique Nord et Central. Publications du Centre National pour l'Exploitation des Océans, Paris.

Olivet, J.-L., Le Pichon, X., Monti, S., and Sichler, B., 1974. CharlieGibbs fracture zone. J. Geophys. Res., 79:2059-2072.

Pastouret, L., Beuzart, P., and Monti, S., 1982. Présentation de cartes bathymétriques de la marge continentale armoricaine et celte, golfe de Gascogne. Bull. Soc. Geol. France, 24:407-411.

Pautot, G., Renard, V., Auffret, G. A., Pastouret, L., and de Charpal, O., 1976. A granite cliff deep in the North Atlantic. Nature, 263: 669-672.

Pegrum, R. M., and Mounteney, N., 1978. Rift basins flanking North Atlantic Ocean and their relation to North Sea area. Am. Assoc. Petrol. Geol. Bull., 62:419-441.

Renard, V., and Allenou, J.-P., 1979. Le Sea-Beam, sondeur à multifaisceaux du N/O Jean Charcot. Description, évaluation et premiers résultats. Rev. Hydrogr. Int. (Monaco), 56:35-71. 
Russell, M. J., and Smythe, D. K., 1983. Origin of the Oslo graben in relation to the Hercynian-Alleghenian orogeny and lithospheric rifting in the North Atlantic. Tectonophysics, 94:457-472.

Savostin, L. A., Sibuet, J.-C., Zonenshain, L. P., and LePichon, X., in press. Kinematic evolution of Tethys. Tectonophysics.

Sibuet, J.-C., 1972. Contribution de la gravimétrie à l'étude de la Bretagne et du plateau continental adjacent. Compt. Rend. Soc. Geol. France, 3:124-128.

1973. South Armorican shear zone and continental fit before the opening of the Bay of Biscay. Earth. Planet. Sci. Lett., 18: 153-157.

Sibuet, J. C., and Mascle, J., 1978. Plate kinematic implications of Atlantic equatorial fracture zone trends. J. Geophys. Res., 44: 601-624.

Somers, M. L., Carson, R. M., Revie, J. A., Edge, R. H., Barrow, B. J., et al., 1978. GLORIA II: an improved long-range sidescan so- nar. Oceanology International: London (B. P. S., Exhibitions, Ltd.), pp. 16-24.

Vail, P. R., Mitchum, R. M., and Thompson, S., III. 1977. Seismic stratigraphy and global changes of sea level, part 3: relative changes of sea level coastal onlaps. Mem. Am. Assoc. Petrol. Geol., 26: 63-81.

Van Eysinga, F. W. B., 1975. Geological Time Table (3rd ed.): Amsterdam (Elsevier).

Ziegler, P. A., 1978. Northwestern Europe: tectonics and basin development. Geol. Mijnbouw, 57:589-626.

1981. Evolution of sedimentary basins in north-west Europe. In Illing, L. V., and Hobson, G. D. (Eds.), Petroleum Geology of the Continental Shelf of North-West Europe: London (Institute of Petroleum), pp. 9-36.

Date of Initial Receipt: February 15, 1984

Date of Acceptance: April 5, 1984 